\title{
MicroRNA dysregulation in B-cell non-Hodgkin lymphoma
}

This article was published in the following Dove Press journal:

Blood and Lymphatic Cancer: Targets and Therapy

7 May 2013

Number of times this article has been viewed

\author{
Emilia L Lim' \\ Marco A Marra ${ }^{1,2}$ \\ 'Canada's Michael Smith Genome \\ Sciences Centre, BC Cancer Agency, \\ Vancouver, BC, Canada; ${ }^{2}$ Department \\ of Medical Genetics, University of \\ British Columbia, Vancouver, BC. \\ Canada
}

\begin{abstract}
B-cell non-Hodgkin lymphomas (NHLs) are lymphoproliferative disorders that can arise at different stages of B-cell development. Even though molecular classification of NHL has allowed for more accurate recognition of distinct aggressive lymphoma subtypes, many patients still fail to respond to standard therapy. As such, there is a need to identify biomarkers and therapeutic targets that can lead to more specific treatments for each NHL patient's disease. MicroRNAs (miRNAs) are small, 17-25 nt RNA molecules that regulate gene expression at the posttranscriptional level. miRNA expression and function is often coordinately dysregulated in NHL, and consequently results in each NHL disease type harboring a distinct miRNA expression signature. miRNA dysregulation may be a consequence of several mechanisms, ranging from dysregulation of the DNA sequences encoding the miRNA to transcriptional regulation of miRNA loci, to dysregulation of the miRNA biogenesis pathway or dysregulation of messenger RNA (mRNA) targets. This coordinated dysregulation of miRNA expression systematically results in the activation of several oncogenic pathways, and consequently the reprogramming of B-cell NHL transcriptomes. The widespread dysregulation of miRNAs suggests that miRNAs may be used as a diagnostic and prognostic tool, and also as actionable drug targets. In this review, we summarize the miRNA profiles of the most common B-cell NHLs, discuss the causes and consequences of miRNA dysregulation, and consider the prospects of miRNA-based biomarkers and therapeutic targets in NHL.
\end{abstract}

Keywords: miRNA, non-Hodgkin lymphoma, dysregulation, therapy

\section{Introduction}

B-cell non-Hodgkin lymphomas (NHLs) are a group of lymphoproliferative disorders that can arise at different stages of B-cell development. ${ }^{1}$ Classification of NHLs has mostly been based on immunohistochemical staining and the presence of particular genomic translocations. More recently, molecular profiling has revealed that some NHL subtypes, which are indistinguishable under the microscope, arise from different B-cell developmental stages and utilize distinct oncogenic programs., ${ }^{2,3}$ Even though molecular classification of NHL has allowed for more accurate recognition of distinct lymphoma subtypes, many patients still fail to respond to standard therapy. ${ }^{4}$ This is likely due to the inherent molecular heterogeneity within each NHL type and the unclear distinctions between NHL types. As such, the identification of other biomarkers and therapeutic targets can offer a better prognosis for each NHL patient.

One category of putative biomarkers and therapeutic targets for NHL and other cancers is the microRNAs (miRNAs). miRNAs are small, 17-25 nt RNA molecules that regulate gene expression at the posttranscriptional level. They were first discovered 
in the context of regulating developmental gene expression patterns in Caenorhabditis elegans. ${ }^{5}$ Since then, many miRNA species have been identified; an online repository, mirBase (version 19), lists 25,141 distinct mature miRNAs in 193 species. ${ }^{6}$ miRNA genes are transcribed into long primary miRNA transcripts (pri-miRNAs), which are then processed in the nucleus to $\sim 70 \mathrm{nt}$ pre-miRNAs by DGCR 8 and the RNase III enzyme Drosha. Pre-miRNAs are then exported to the cytoplasm by exportin 5 and further processed by Dicer to $\sim 22$ nt double-stranded miRNA duplexes. Each doublestranded duplex is loaded onto the Argonaute protein of a miRNA-induced silencing complex (miRISC) and rapidly unwound by helicase. ${ }^{7}$ The mature miRNA acts by directing the miRISC to complementary miRNA binding sites (MBSs) located on messenger RNAs (mRNAs) in order to induce cleavage or translational repression of these mRNA targets. This posttranscriptional regulatory process is known as miRNA-mediated regulation (MMR) and is reviewed in detail by Krol et al. ${ }^{8}$ Perfect complementarity of the miRNA seed region to its mRNA target is typically necessary for mRNA cleavage. In cases where there is imperfect complementarity, only translational repression is achieved (Figure 1). Although it was initially understood that miRNA target the $3^{\prime}$-untranslated regions (UTRs) of mRNA, miRNA can also target the $5^{\prime}$-UTR and coding regions to elicit translational repression ${ }^{9}$ or enhancement. ${ }^{10}$

miRNA:mRNA interactions are complex. A given miRNA may have multiple (up to several hundred) gene targets, and $60 \%$ of mRNAs have binding sites for multiple miRNAs in their $3^{\prime}$-UTRs. ${ }^{11}$ Currently, mirTarBase has enumerated a total of 3576 experimentally verified interactions between 657 miRNAs and 2297 target genes. ${ }^{12}$ Not surprisingly, miRNAs have been involved in the regulation of numerous biological processes, including cellular growth, differentiation, and apoptosis, and its dysregulation has been associated with the pathogenesis of diseases such as cancer. ${ }^{13}$ Many miRNA signatures in cancers have been identified, ${ }^{14}$ some of which comprise genome-wide miRNA profiles that have been shown to be effective at discriminating the differentiation state and developmental lineage of tumors with higher accuracy than

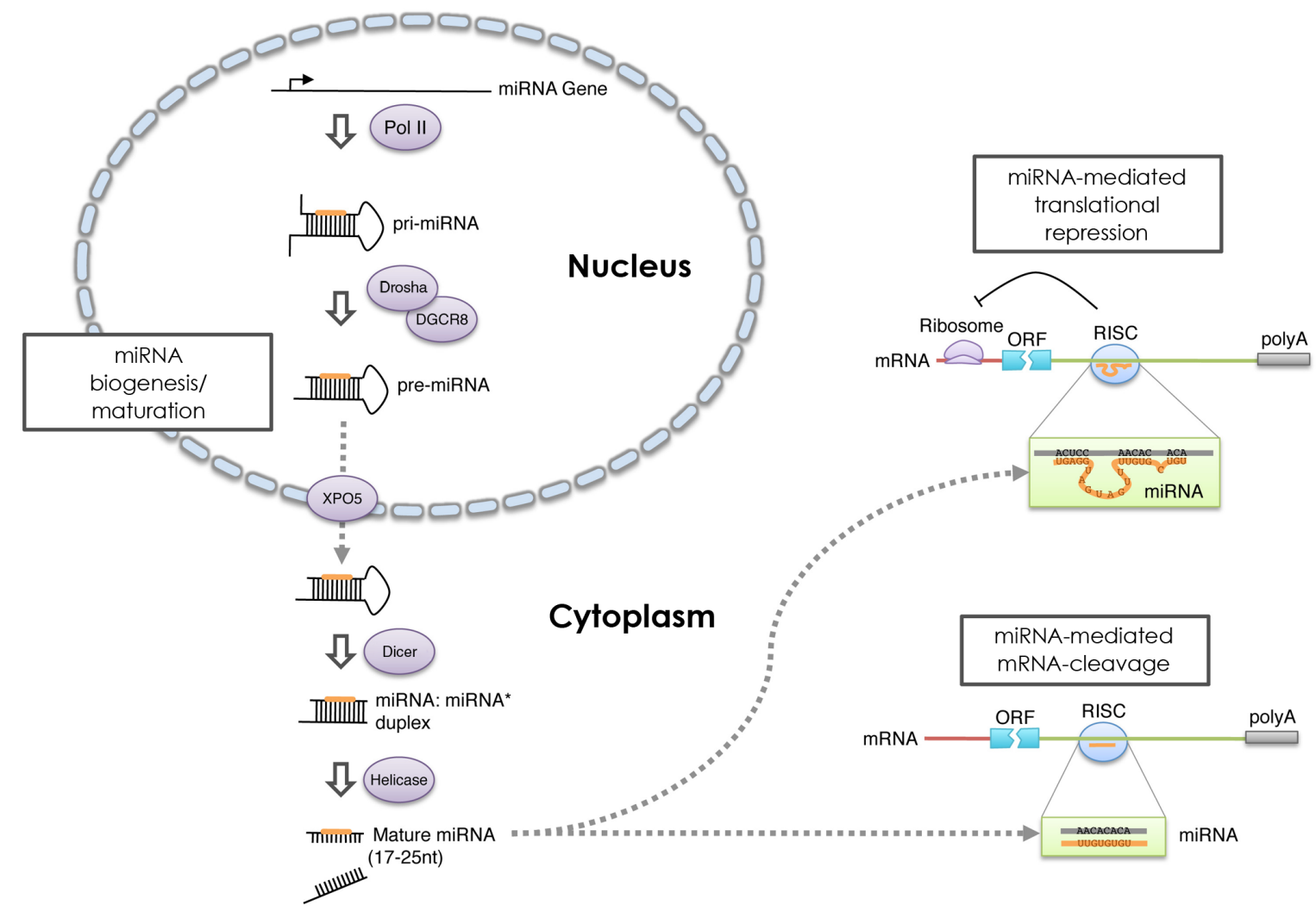

Figure I miRNA biogenesis and function.

Notes: miRNA are transcribed in the nucleus into pri-miRNA, which are processed by the Drosha and DGRC8 complex. The premiRNA are then exported to the cytoplasm by XPO5 and further processed by Dicer into miRNA:miRNA* duplexes. Helicase unwinds the duplex, leaving the mature miRNA strands free to associate with the RISC complex to direct mRNA targeting. miRNA:mRNA interacting pairs with perfectly complementary sequences result in the cleavage of target mRNA, whereas partial complementarity achieves translational repression.

Abbreviations: DGRC8, DiGeorge syndrome critical region gene 8; ORF, open reading frame; Polll, RNA polymerase II; polyA, polyadenylic acid tail; RISC, RNA-induced silencing complex; XPO5, Exportin 5. 
mRNA profiles. ${ }^{15}$ The role of miRNAs in B-cell lineage and development has been reviewed by Fernando et $\mathrm{al}^{16}$ and Sandhu et al. ${ }^{17}$

Underlying the aberrant expression of miRNA are various mechanisms of miRNA dysregulation, including structural alterations, chromatin remodeling, aberrant transcription factor activity, and disruptions to the miRNA biogenesis pathway. In 2002 , Calin et $\mathrm{al}^{18}$ provided the first evidence of the involvement of miRNA dysregulation in the pathogenesis of B-cell cancers, where they revealed that a genomic deletion at chromosome $13 \mathrm{q} 14$ resulted in the loss of miR-15 and miR-16 expression in $68 \%$ of B-cell chronic lymphocytic leukemia cases. Since then, NHL molecular profiling efforts have begun to examine the causes and consequences of miRNA dysregulation, and these efforts were first reviewed by Lawrie. ${ }^{19}$ Specific miRNAs have been found to characterize various subtypes of NHL and have essential roles in B-cell differentiation and lymphomagenesis, ${ }^{20-22}$ and their associations with the pathogenesis of NHL has recently been reviewed by Auer ${ }^{23}$ and Di Lisio et al. ${ }^{24}$ The frequency of aberrant expression of miRNA NHL subtypes suggests that drug therapy aimed at correcting the expression of these dysregulated miRNA, whether by directly modulating miRNA levels or by targeting the dysregulated miRNA regulatory mechanism, could improve patient survival. In this review, we summarize the miRNA profiling efforts that have identified dysregulated miRNA in the most common B-cell NHLs (Table 1). We then focus our discussion on the causes and consequences of miRNA dysregulation. Finally, we conclude with future prospects of miRNA-based biomarkers and therapeutic targets in NHL.

\section{NHL types have distinct miRNA expression profiles \\ Diffuse large B-cell lymphoma (DLBCL)}

DLBCL is the most common kind of NHL, accounting for almost $30 \%-40 \%$ of newly diagnosed lymphomas. ${ }^{1}$ DLBCL tumors are characterized by upregulated expression of miR-150, miR-17-5p, miR-145, and miR-328 when compared with samples from normal lymph nodes and follicular lymphoma (FL). ${ }^{25}$ Since miRNA expression tends to be tissue specific, miRNA expression profiles differ based on the primary tumor site. When miRNA expression was compared between central nervous system, testicular, and nodal DLBCL samples, miR-17 was upregulated in DLBCL

Table I miRNA expression signatures of the most common NHLs

\begin{tabular}{|c|c|c|c|c|}
\hline Disease & Subtype & Upregulated miRNA & Downregulated miRNA & Reference \\
\hline \multirow[t]{8}{*}{ DLBCL } & $A B C$ and $G C B$ & miR-I50, miR-I7-5p, miR-I45, and miR-328 & - & 25 \\
\hline & $A B C$ vs $G C B$ & miR-I55, miR-2I, miR-22I & - & 29 \\
\hline & GCB & miR-17-92 Cluster & - & 27 \\
\hline & $A B C$ vs $G C B$ & $\begin{array}{l}\text { miR-146a, miR-I46b, miR-2I, miR-I55, miR-500, } \\
\text { miR-22, miR-363, miR-574 }\end{array}$ & - & 21 \\
\hline & $A B C$ vs $G C B$ & $\begin{array}{l}\text { miR-17, miR-19b, miR-20a, miR-29a, miR-92a, } \\
\text { miR-106a, miR-720, miR-1260, miR-1280 }\end{array}$ & - & 28 \\
\hline & Central nervous system & miR-I7 & - & 26 \\
\hline & Testicular & $\operatorname{miR}-127$ & - & 26 \\
\hline & Transformed from FL & miR-223, miR-2I7, miR-222, miR-22I, let-7i, let-7b & - & 31 \\
\hline \multirow[t]{2}{*}{$\mathrm{FL}$} & & miR-9, miR-9*, miR-30I, miR-338, miR-213 & - & 25 \\
\hline & & $\begin{array}{l}\text { miR-193a, miR-193b, miR-345, miR-5I3b, } \\
\text { miR-574, miR-54, miR-663, miR-I287, } \\
\text { miR-I295, miR-I47I }\end{array}$ & $\begin{array}{l}\text { miR-I7, miR-30a, miR-33a, miR-I06a, } \\
\text { miR-I4I, miR-202, miR-205, miR-222, } \\
\text { miR-30Ib, miR-43I, miR-570 }\end{array}$ & 30 \\
\hline BL & $\mathrm{eBL}$ and $\mathrm{sBL}$ vs $\mathrm{DLBCL}$ & $\begin{array}{l}\text { miR-37I, miR-185, miR-93, miR-326, miR-497, } \\
\text { miR-26b, miR-339, miR-485, miR-9, miR-193a, } \\
\text { miR-448, miR-202, miR-483, miR-26a, miR-328, } \\
\text { miR-192, miR-429, miR-324, miR-340, miR-105, } \\
\text { miR-124 }\end{array}$ & $\begin{array}{l}\text { miR-22I, miR-I55, miR-I46a, miR-I46b, } \\
\text { miR-26b, miR-23a, miR-30d, miR-107, } \\
\text { miR-103, miR-222, miR-26a, miR-30a, } \\
\text { miR-I42, miR-23b, miR-342, miR-29b, } \\
\text { miR-34b }\end{array}$ & 33 \\
\hline $\mathrm{MCL}$ & & $\begin{array}{l}\text { miR-17-92, miR-106b, miR-93 and miR-25, } \\
\text { miR-617, miR-370, miR-654, mrR-124a, miR-155, } \\
\text { miR-302c, miR-345, miR-373* and miR-210 }\end{array}$ & $\begin{array}{l}\text { miR-I50 and miR-I42, miR-3I, } \\
\text { miR-I48a, miR-27b }\end{array}$ & 101 \\
\hline CLL & & & miR-I5, miR-I6 & 18 \\
\hline
\end{tabular}

Notes: The subtype column indicates which subgroups within the disease were compared against when observing for differential expression of miRNA. If no comparator is stated, the disease type was compared against an equivalent of normal B-cells.

Abbreviations: $A B C$, activated B-cell-like subtype; $B L$, Burkitt's lymphoma; $C L L$, chronic lymphocytic leukemia; $D L B C L$, diffuse large $B$-cell lymphoma; eBL endemic $B L$ subtype; FL, follicular lymphoma; GCB, germinal center B-cell-like subtype; MCL, mantle-cell lymphoma; sBL, sporadic BL subtype. 
tumors arising from within the central nervous system, while miR-127 was upregulated in DLBCL tumors arising from within the testis. ${ }^{26}$ Although DLBCL cases have a common morphology, they are noted for their striking clinical and molecular variability. Gene expression profiling has revealed at least three DLBCL subtypes that have different genetic aberrations and clinical outcome. ${ }^{3}$ Activated B-cell-like (ABC) subtype tumors arise from plasmablasts, while germinal center B-cell-like (GCB) subtype tumors arise from germinal center B-cells. These two subtypes can be distinguished not only by gene expression profiles but also by distinct miRNA expression profiles. In particular, the miR-17-92 cluster of miRNAs are significantly upregulated in GCB-DLBCL tumors compared with ABC-DLBCL and B-cell controls. ${ }^{27,28}$ As well, miR-155, miR-221, and miR-21 are more highly expressed in ABC-DLBCL when compared with GCB-DLBCL. ${ }^{21,29}$

\section{Follicular lymphoma (FL)}

FL is another NHL that is also derived from germinal center B-cells. A comparison between miRNA expression profiles of FL and DLBCL revealed several miRNA that are overexpressed in both cancers (miR-155, miR-210, miR-106a, miR-149, and miR-139) when compared with normal lymph nodes. This suggests that these frequently overexpressed miRNAs could play significant roles in lymphomagenesis. ${ }^{25}$ However, despite this similarity, FLs still have a miRNA signature that is distinct from DLBCL - one that is related to cell proliferation and tumor response. When comparing FL tumor cells with normal germinal center B-cells, miR-20a/b and miR-194 are overexpressed in FL and they target cell proliferation inhibitors $C D K N 1 A$ and SOCS2, respectively. ${ }^{30}$ Although considered an indolent disease, a significant proportion of FL cases may undergo a transformation to an aggressive DLBCL with a poorer outcome. A miRNA signature consisting of four upregulated miRNAs (let-7b, let-7i, miR-221, and miR-222), and two downregulated miRNAs (miR-223 and miR-217), when comparing transformed DLBCL cases to normal DLBCL cases, can predict this transformation. ${ }^{31}$

\section{Burkitt's lymphoma (BL)}

$\mathrm{BL}$ is an aggressive NHL characterized by a high degree of proliferation of the malignant cells. Most BL tumors demonstrate dysregulation of the $M y c$ gene as a consequence of chromosome 8q24 translocations that place $M y c$ under the regulation of immunoglobulin gene regulatory elements. ${ }^{32}$ There are three BL subtypes: a sporadic subtype that is diagnosed in developed countries, the Epstein-Barr virus (EBV)-associated endemic subtype, and an HIV-associated subtype. Despite differences in their geographical occurrence and incidence of viral infection, these BL subtypes represent a uniform biological entity: molecular profiling revealed that sporadic and endemic subtypes only differ marginally by the expression of six miRNA and that the viral-induced nature of BL tumors had no significant impact on miRNA expression. ${ }^{33}$ However, just as BL tumors and DLBCL tumors differ in their protein-coding gene expression profiles, ${ }^{34} \mathrm{BL}$ tumors also have a miRNA signature that is distinct from that of DLBCL. Unlike DLBCL, BL tumors underexpress miR-155 compared to normal B-cells. ${ }^{35}$

\section{Mantle-cell lymphoma (MCL)}

MCL tumors are relatively more homogeneous and more resistant to chemotherapy than tumors of other lymphomas. MCL tumors harbor the chromosomal translocation $\mathrm{t}(11 ; 14)$ (q13;q32), which results in aberrant expression of CCND1, a key regulator of the cell cycle. Since MCL is characterized by deregulation of several survival signaling pathways, ${ }^{36}$ this translocation alone does not explain all the dysregulation in MCL tumors. At the miRNA level, MCL is characterized by a downregulation of miR-29, ${ }^{37} \mathrm{miR}-15 \mathrm{a}$, and $\mathrm{miR}-16-1,{ }^{38}$ and an upregulation of the miR-17-92 cluster $^{39}$ when compared with normal B-cells.

\section{miRNA dysregulation contributes to tumorigenesis}

Dysregulation of miRNA may result in the aberrant expression of miRNA target genes (Figure 2; Table 2), and, in many instances, this disruption of gene expression results in the acceleration of lymphomagenesis. In agreement with this, several miRNAs have expression patterns that have been found to be associated with NHL patient prognosis (Table 3).

\section{miRNA as tumor suppressors}

miRNAs that are responsible for repression of genes that would otherwise contribute to tumorigenesis can be classified as tumor suppressors. These tumor-suppressive miRNAs are typically repressed or lost in malignancy. In some instances, this loss results in the miRNA exacerbating the aberrant expression of target genes that may have already been dysregulated by other mechanisms, such as copy number alterations or translocations. For instance, miR-34a is downregulated by Myc, in DLBCL, and the result of this is increased cell proliferation through a FOXP1-dependent 


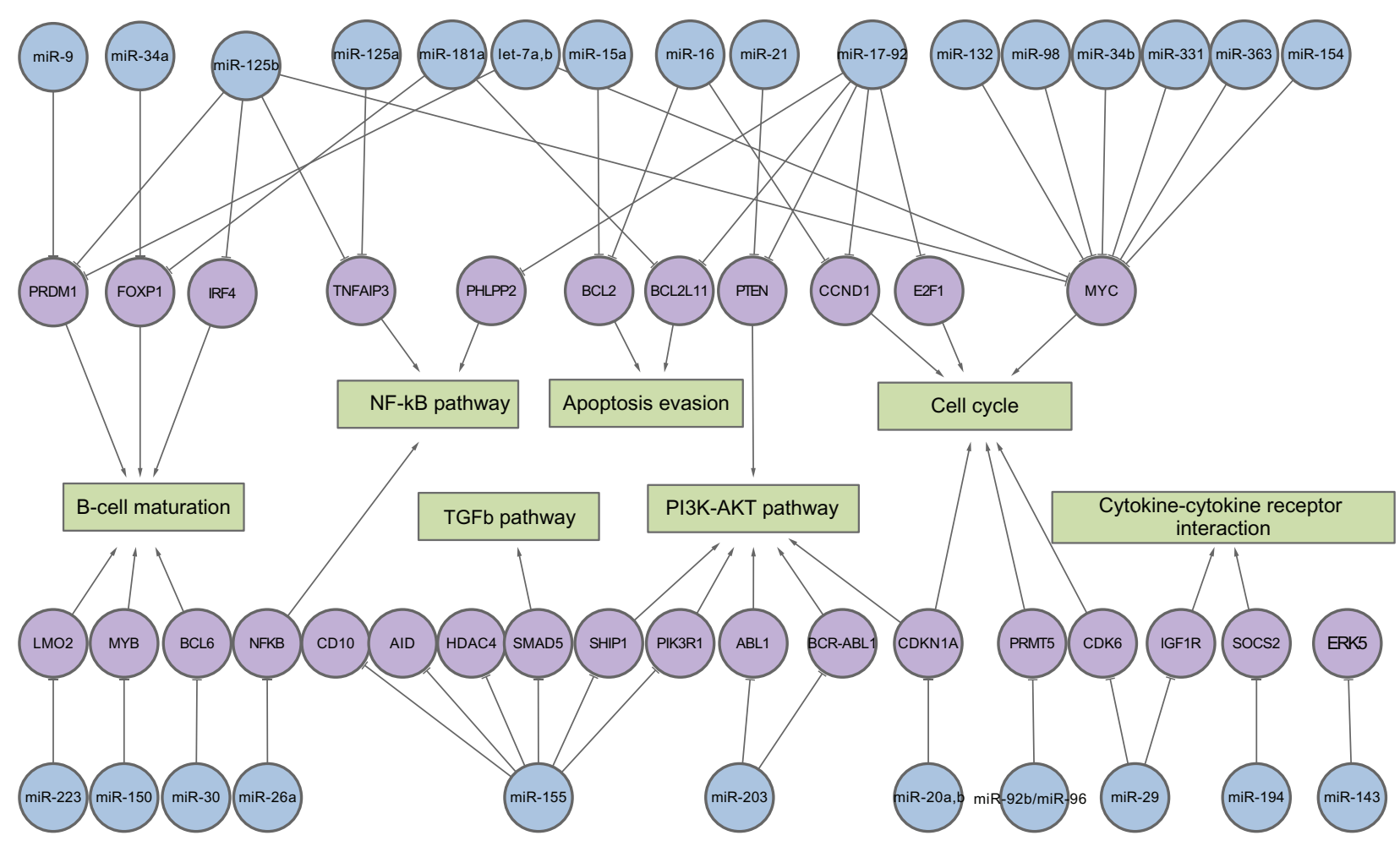

Figure 2 Validated miRNA:mRNA interactions in B-cell non-Hodgkin lymphoma.

Notes: Experimentally determined miRNA:mRNA interactions in B-cell non-Hodgkin lymphoma contexts. Blue circles represent miRNA, purple circles represent genes, and green boxes represent oncogenic pathways or processes affected by the targeted genes.

Abbreviations: AKT, Protein Kinase B; miRNA, microRNA; NF-kB, nuclear factor kappa-light-chain-enhancer of activated B cells; PI3K, Phosphatidylinositide 3-kinase; TGF-b, Transforming growth factor beta.

tumorigenesis pathway. ${ }^{40}$ Similarly, miR-15a and miR-16-1 loci are lost in DLBCL ${ }^{41}$ and $\mathrm{MCL}^{42}$ and this loss contributes to tumorigenesis through the de-repression of their oncogenic targets, including anti-apoptotic $B C L 2$, and the cell cycle regulator $C C N D 1 .{ }^{43}$ In addition, the combinatorial loss of multiple miRNAs could synergistically contribute to tumorigenesis. For instance, a protein that is required for CCND1 activity, CDK6, is also upregulated (amongst other miRNAs) due to the loss of miR-29. ${ }^{44}$ Another example is that of the miRNAs that target Myc. In BL, Myc is only successfully de-repressed in the absence of abundant let- $7 \mathrm{a} / \mathrm{b}$, miR-125b, miR-132, miR-154, miR-331, and miR-363. Interestingly, the expression of these miRNAs is repressed by Myc, suggesting a Myc-miRNA feed-forward loop that may drive tumorigenesis. ${ }^{45}$

\section{miRNA as oncogenes}

miRNAs that are overexpressed or amplified in malignancy can result in the repression of tumor-suppressor genes. These miRNAs can be classified as oncogenic miRNA or oncomiRs. For instance, miRNAs from the miR-17-92 cluster are frequently upregulated in NHLs when compared with normal B-cells. Their overexpression facilitates cell proliferation and inhibits apoptosis in B-cells by exerting translational repression on multiple target genes including proapoptotic BCL2L11 and tumor suppressor PTEN. ${ }^{46}$ miR-17-92 may also contribute to tumorigenesis by activating members of the PI3K/AKT pathway. In addition, the increased repressive effects of miR-17-92 on its target genes in vivo compared with in vitro suggests that miR-17-92 also regulates the tumor microenvironment, thus accelerating tumorigenesis. In particular, miR-17-92 promotes angiogenesis through suppressing the anti-angiogenic thrombospondin (THBS)-1 and connective tissue growth factor (CTGF), or by inhibiting members of the transforming growth factor (TGF) $\beta$ pathway. ${ }^{47}$

Since a single miRNA species can regulate the expression of multiple genes, miRNA expression levels must be carefully regulated to ensure cellular homeostasis. Despite its oncogenic effects when overexpressed, miR-17-92 expression is essential for B-cell development - its deletion in mice results in neonatal lethality, congenital cardiac malformations, and improper B-cell development. ${ }^{48}$ The same is true of miR-155, where either overexpression or underexpression compared with normal B-cells results in tumorigenesis: underexpression of miR-155 is characteristic 
Table 2 Experimentally determined miRNA:mRNA interactions

\begin{tabular}{|c|c|c|c|c|}
\hline miRNA & Gene & Context/disease & Comments & Reference \\
\hline let-7a,b & MYC & $\mathrm{BL}$ & Cell cycle & 45 \\
\hline let-7b & PRDMI & DLBCL & B-cell maturation & 102,103 \\
\hline $\operatorname{miR}-125 a$ & TNFAIP3 & DLBCL & NF-kB pathway & 104 \\
\hline miR-125b & MYC & $\mathrm{BL}$ & Cell cycle & 45 \\
\hline miR-I25b & TNFAIP3 & DLBCL & NF-kB pathway & 104 \\
\hline$m i R-125 b$ & IRF4 & GCB cells & B-cell maturation & 21 \\
\hline$m i R-125 b$ & PRDM I & GCB cells & B-cell maturation & 21 \\
\hline miR-132 & MYC & $\mathrm{BL}$ & Cell cycle & 45 \\
\hline miR-I43 & ERK5 & B-cell NHL & & 105 \\
\hline miR-I50 & MYB & B-cell differentiation & B-cell maturation & 106 \\
\hline miR-I54 & MYC & $\mathrm{BL}$ & Cell cycle & 45 \\
\hline miR-I55 & AID & B-cell & & 107 \\
\hline miR-I55 & AID & $\mathrm{BL}$ & AID induces MYC-IGH translocation & 50 \\
\hline miR-I55 & $C D / 0$ & $\mathrm{BL}$ & & 108 \\
\hline miR-I55 & PIK3RI & DLBCL & PI3K-AKT pathway & 51 \\
\hline miR-I55 & SHIPI & DLBCL & PI3K-AKT pathway & 109 \\
\hline miR-I55 & SMAD5 & DLBCL & TGF $\beta$ pathway & 52 \\
\hline miR-I55 & $C D I 0$ & DLBCL & & 108 \\
\hline miR-I55 & HDAC4 & B-cell NHL & Targets BCL6 & 53 \\
\hline $\operatorname{miR}-15 \mathrm{a}$ & $B C L 2$ & CLL & Apoptosis evasion & 110 \\
\hline miR-16 & $B C L 2$ & CLL & Apoptosis evasion & 110 \\
\hline $\operatorname{miR}-16$ & CCNDI & $\mathrm{MCL}$ & Cell cycle & 43 \\
\hline miR-17-92 & E2FI & B-cell NHL & Cell cycle & 64 \\
\hline miR-17-92 & $B C L 2 L I I$ & B-cell NHL & Apoptosis evasion & 46 \\
\hline miR-17-92 & CCNDI & $\mathrm{MCL}$ & Cell cycle & 43,81 \\
\hline miR-17-92 & PTEN & MCL & PI3K-AKT pathway & 111 \\
\hline miR-17-92 & PHLPP2 & $\mathrm{MCL}$ & NF-kB pathway & 47,111 \\
\hline miR-I8Ia & FOXPI & DLBCL & B-cell maturation & 112 \\
\hline miR-I8Ia & $B C L 2 L I I$ & $\mathrm{MCL}$ & Apoptosis evasion & 113 \\
\hline miR-194 & SOCS2 & $\mathrm{FL}$ & Cytokine-cytokine receptor interaction & 30 \\
\hline miR-203 & $A B L I$ & $\begin{array}{l}\text { Hematopoietic } \\
\text { malignancies }\end{array}$ & PI3K-AKT pathway & 114,115 \\
\hline $\mathrm{miR}-20 \mathrm{a} / \mathrm{b}$ & CDKNIA & $\mathrm{FL}$ & Cell cycle; PI3K-AKT pathway & 30 \\
\hline miR-2I & PTEN & DLBCL & $\begin{array}{l}\text { Impacts the PI3K-AKT pathway, thereby } \\
\text { affecting cellular sensitivity to the CHOP } \\
\text { chemotherapeutic regimen }\end{array}$ & 99 \\
\hline miR-223 & LMO2 & Memory B-cells & B-cell maturation & 21 \\
\hline miR-26a & NFKB & $\mathrm{MCL}$ & NF-kB pathway & 101 \\
\hline $\operatorname{miR}-29$ & $I G F I R$ & $\mathrm{MCL}$ & Cytokine-cytokine receptor interaction & 37 \\
\hline miR-29 & CDK6 & $\mathrm{MCL}$ & Cell cycle & 44 \\
\hline $\operatorname{miR}-30$ & $B C L 6$ & B-cell NHL & B-cell maturation & 103 \\
\hline miR-33I & MYC & $\mathrm{BL}$ & Cell cycle & 45 \\
\hline miR-34a & FOXPI & MALT/DLBCL & B-cell maturation & 40 \\
\hline miR-34b & MYC & $\mathrm{BL}$ & Cell cycle & 116 \\
\hline $\operatorname{miR}-363$ & MYC & $\mathrm{BL}$ & Cell cycle & 45 \\
\hline miR-9 & PRDMI & B-cell NHL & B-cell maturation & 103 \\
\hline miR-92b & PRMT5 & $\mathrm{MCL}$ & Cell cycle & 117 \\
\hline miR-96 & PRMT5 & $M C L$ & Cell cycle & 117 \\
\hline miR-98 & MYC & BL & Cell cycle & 118 \\
\hline
\end{tabular}

Abbreviations: BL, Burkitt's lymphoma; CHOP, cyclophosphamide, doxorubicin, vincristine, prednisone; CLL, chronic lymphocytic leukemia; DLBCL, diffuse large B-cell lymphoma; FL, follicular lymphoma; GCB, germinal center B-cell-like subtype; MALT, mucosa-associated lymphoid tissue type; MCL, mantle-cell lymphoma; NHL, non-Hodgkin lymphoma.

of BL, while its overexpression is frequent in DLBCL. ${ }^{49}$ The loss of miR-155 in BL results in an overabundance of activation-induced deaminase (AID), which is involved in the deamination of cytosine residues and introduction of $\mathrm{U}: \mathrm{G}$ mismatches in DNA and consequently results in
DNA instability. As such, an abundance of AID typically results in increase of $\mathrm{Myc}-\mathrm{IGH}$ translocations and thus the aberrant expression of oncogenic Myc. ${ }^{50}$ On the other hand, an overabundance of miR-155 contributes to tumorigenesis by dysregulating the expression of members 
Table 3 miRNA associated with patient prognosis

\begin{tabular}{|c|c|c|c|}
\hline miRNA & Disease & Clinical variability & Reference \\
\hline miR-I48a & DLBCL & High expression after R-CHOP chemotherapy correlates with poor outcome & 123 \\
\hline miR-|5I & DLBCL & High expression after R-CHOP chemotherapy correlates with poor outcome & 123 \\
\hline miR-I55 & DLBCL & High expression correlates with poor outcome, and indicates a better response to rituximab treatment & 124 \\
\hline miR-I8Ia & DLBCL & High expression after R-CHOP chemotherapy correlates with poor progression-free survival & 112 \\
\hline miR-18a & DLBCL & High expression after R-CHOP chemotherapy correlates with poor overall survival & 112 \\
\hline miR-200c & DLBCL & High expression correlates with poor outcome & 125 \\
\hline miR-20b & $\mathrm{MCL}$ & High expression correlates with poor outcome & 101 \\
\hline miR-2I & DLBCL & High expression correlates with poor outcome & 29 \\
\hline miR-22I & DLBCL & High expression after R-CHOP chemotherapy correlates with poor outcome & 123 \\
\hline miR-222 & DLBCL & High expression after R-CHOP chemotherapy correlates with poor outcome & 21,123 \\
\hline miR-222 & DLBCL & High expression after R-CHOP chemotherapy correlates with poor progression-free survival & 112 \\
\hline miR-222 & DLBCL & High expression after R-CHOP chemotherapy correlates with poor outcome & 123 \\
\hline miR-28 & DLBCL & High expression after R-CHOP chemotherapy correlates with poor outcome & 123 \\
\hline miR-29 & $\mathrm{MCL}$ & High expression correlates with poor outcome & 44 \\
\hline miR-33I & DLBCL & High expression after R-CHOP chemotherapy correlates with poor outcome & 123 \\
\hline miR-45। & DLBCL & High expression after R-CHOP chemotherapy correlates with poor outcome & 123 \\
\hline miR-49| & DLBCL & High expression after R-CHOP chemotherapy correlates with poor outcome & 123 \\
\hline miR-93 & DLBCL & High expression after R-CHOP chemotherapy correlates with poor outcome & 123 \\
\hline Profile of miRNA & $\mathrm{FL}$ & High expression correlates with poor outcome & 30 \\
\hline
\end{tabular}

Abbreviations: $\mathrm{CHOP}$, cyclophosphamide, doxorubicin, vincristine, prednisone; DLBCL, diffuse large B-cell lymphoma; FL, follicular lymphoma; $\mathrm{MCL}$, mantle-cell lymphoma; $\mathrm{NHL}$, non-Hodgkin lymphoma.

of the PI3K-AKT pathway, ${ }^{51}$ the TGF $\beta$ pathway, ${ }^{52}$ and other transcriptional regulators. ${ }^{53}$ These findings illustrate the prevalence of miRNA dysregulation in NHLs and emphasize the importance of maintaining specific levels of miRNA expression within the cell.

\section{Causes of miRNA dysregulation Copy number alterations}

miRNA dysregulation may result from a variety of causes (Table 4). miRNAs can be dysregulated due to changes in the underlying DNA that encodes them. One category of such genetic alterations is DNA copy number alterations. Due to the nature of copy number alterations affecting large segments of genomic DNA, the same aberration may affect clusters of several miRNAs. A genome-wide study of miRNA expression and copy number in DLBCL identified 63 individual miRNAs, including 28 miRNA clusters, that displayed recurrent copy number changes. One-third of these miRNAs were also found to be part of a tumor-driven classifier, suggesting the significance of copy number alterations in miRNA dysregulation in DLBCL. ${ }^{41}$

Since copy number alterations tend to be NHL subtypespecific, miRNA dysregulation due to copy number alterations vary across B-cell NHL types. In BL, the deletion at chromosome $14 \mathrm{q} 32$ results in the downregulation of miR-203, miR-134, and miR-154 when compared with normal lymph nodes. ${ }^{45}$ In DLBCL, the amplification at chromosome 11 results in the upregulation of miR-100,
miR-125b-1, and miR-130a. ${ }^{41}$ Disruption of chromosome $\mathrm{X}$ copy number is common in DLBCL, ${ }^{54}$ and this results in several miRNAs encoded on chromosome $\mathrm{X}$ being frequently amplified (miR-513, miR-223, miR-424). ${ }^{41}$ This suggests that tumors with chromosome $\mathrm{X}$ disruption may acquire a growth advantage through miRNA dysregulation.

There are particular copy number alterations that are more frequent in particular subtypes of DLBCL. All DLBCL tumors have ten- to 30-fold higher copy numbers of miR-155 when compared with normal circulating B-cells, but ABCDLBCL two- to three-fold higher levels of miR-155 than GCB-DLBCL. Not surprisingly, upregulation of miR-155 in ABC-DLBCL is attributed to the amplification of chromosome 21q21, which has been associated with inferior outcome in NHL patients. ${ }^{49}$ Similarly, gains of chromosome $12 q$ are more frequently associated with tumors classified as the GCB-DLBCL ${ }^{54}$ or MCL. ${ }^{47}$

\section{Translocations}

miRNAs are frequently located at fragile sites and genomic regions involved in cancers, ${ }^{55}$ and may be a cause of miRNA loss or gain. In DLBCL, the $\mathrm{t}(3 ; 7)(\mathrm{q} 27 ; \mathrm{q} 32)$ translocation fuses $B C L 6$ to a noncoding region at $F R A 7 H$ near miR-29, thereby downregulating the expression of miR-29. ${ }^{56,57}$ Similarly, a complex BCL6 rearrangement $\mathrm{t}(3 ; 13)(\mathrm{q} 27 ; \mathrm{q} 31) \mathrm{t}(12 ; 13)(\mathrm{p} 11 ; \mathrm{q} 31)$ in DLBCL cells results in a ITPR2-BCL6 chimeric fusion gene rearrangements and places the miR-17-92 cluster antisense within this fusion. 


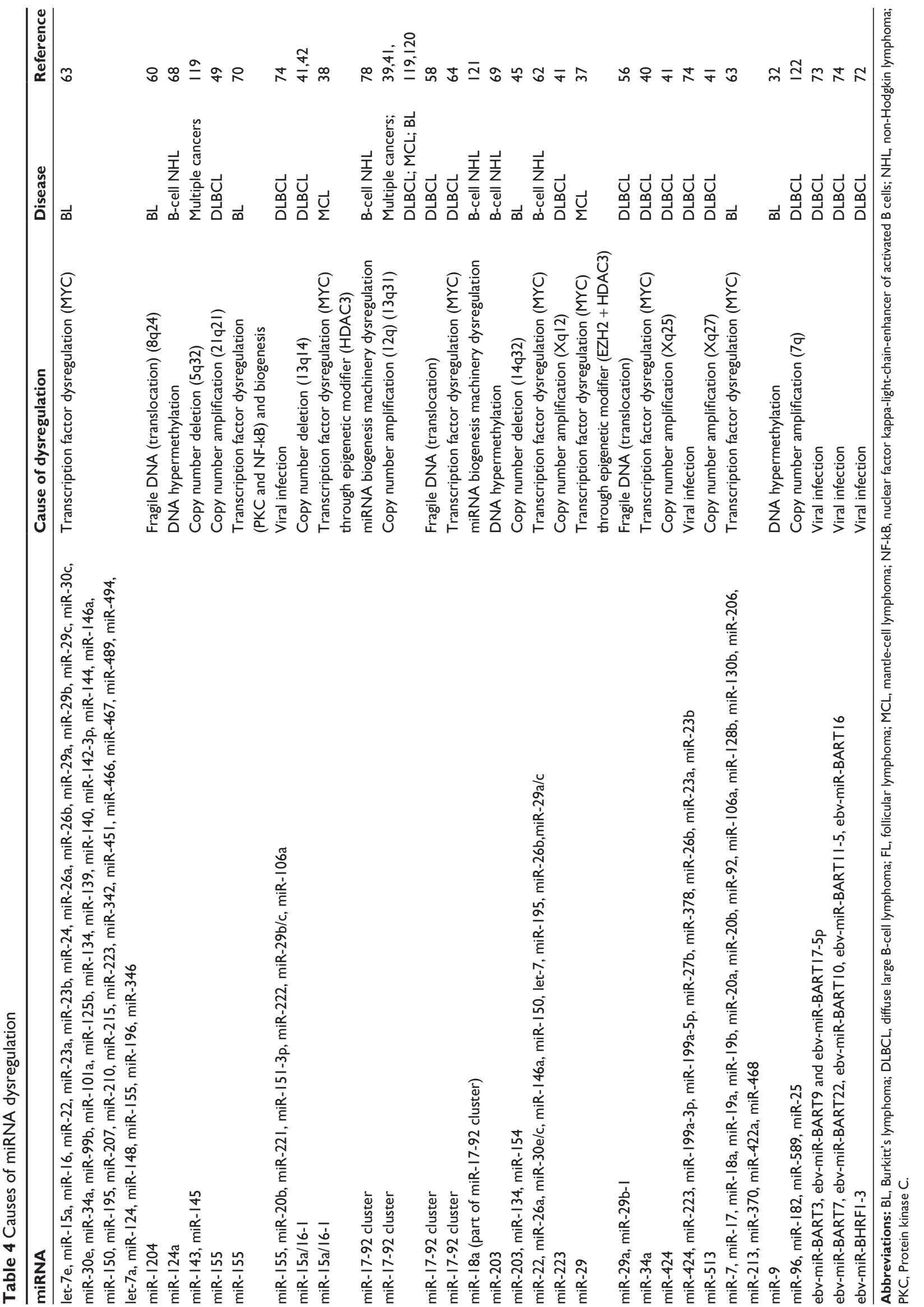


This translocation results in the upregulated expression of the miR-17-92 cluster. ${ }^{58}$ The majority of FL cases $(90 \%)$ are characterized at the karyotype level by the $\mathrm{t}(14 ; 18)(\mathrm{q} 32 ; \mathrm{q} 21)$ translocation - a molecular aberration that is associated with the deregulated expression of miR-16, miR-26a, miR-101, miR-29c, and miR-138. ${ }^{59} \mathrm{In} \mathrm{BL}$, a translocation often results in the PVT1 exon $1 \mathrm{~b}$ region (encoding miR-1204) being fused to the immunoglobulin light chain constant region. This consequently results in the upregulation of miR-1204. ${ }^{60}$ Although the consequences of this translocation are unclear, it is of interest as miR-1204 is the miRNA with closest genomic proximity to Myc, and the possible misregulation of both of these genes concurrently may be a synergistic mechanism of lymphomagenesis.

\section{Aberrant transcription factor activity}

miRNA dysregulation in NHL can also be a result of a disruption of their expression patterns. Transcription factors are essential in regulating the expression of other genes by binding to transcription factor binding sites that are cis-regulatory elements located in close proximity to the transcription start sites of genes. When the expression of transcription factors that target miRNA loci is dysregulated, the expression of their target miRNA is consequently affected. There are several transcription factors that are dysregulated in lymphomagenesis (Table 4), but the most frequently disrupted is Myc.

Myc is a transcription factor that promotes tumorigenesis by activating and repressing target genes that are involved in cell cycle regulation, cell growth differentiation, metabolism, angiogenesis, and cell adhesion and migration. ${ }^{61}$ Given the key role that Myc plays in many pathways of tumorigenesis, it is not surprising that Myc dysregulation is one of the most common abnormalities in cancer. In addition to the regulation of protein-coding genes, a major consequence of Myc upregulation is the extensive reprogramming of miRNA expression patterns in tumors. ${ }^{62}$ When comparing the miRNA expression profiles of BL with those of other B-cell lymphomas, BL cases with high expression of Myc displayed a characteristic pattern of Myc-induced miRNA expression: upregulated miRNAs include the miR-17-92 cluster, and downregulated miRNAs include miR-15a and miR-16. ${ }^{63}$ Myc as a transcription factor does not only result in the activation of transcription, but also represses the transcription of certain miRNAs. In human and mouse models of B-cell lymphoma, Chang et $\mathrm{al}^{62}$ observed that overexpression of Myc results in the widespread repression of several miRNAs. Their chromatin immunoprecipitation analysis further identified 11 miRNAs that were repressed by Myc overexpression.

Myc is a transcription factor with many targets, which may sometimes regulate the expression of particular genes through multiple targets. In DLBCL, Myc binds to the promoter of the miR-17-92 cluster on chromosome 13 and activates its transcription. miRNAs from the miR-17-92 cluster then repress the expression of E2F1, a transcription factor that promotes G1-to-S phase progression. Interestingly, Myc also binds to the $E 2 F 1$ promoter, thereby directly activating its transcription. The collaborative regulatory action on E2F1 (upregulation by Myc and downregulation by miR-17-92) suggests that Myc "uses" the miR-17-92 cluster as a means to fine-tune its regulatory mechanism of proliferation. ${ }^{64}$ The influence of Myc on miRNA is not limited to the direct binding to its promoters to elicit transcriptional activation or repression. Myc may also affect miRNA expression through the dysregulation of chromatin modifiers that target miRNA loci.

\section{Chromatin modification}

Chromatin modification is another mechanism that has a profound effect on the regulation of miRNA expression. Chromatin modification, including DNA methylation, incorporation of histone variants, and posttranslational modifications of histones, imparts epigenetic control of gene expression without disruption to the underlying DNA sequence. These modifications alter the structure of heterochromatin, restricting physical access of nuclear factors, such as transcriptional machinery, to the underlying DNA. ${ }^{65}$ DNA methylation refers to the catalyzing of DNA cytosine to methylcytosine by DNA methyltransferase. The presence of additional methyl groups on DNA residues modulates the accessibility of DNA to transcriptional machinery; DNA hypermethylation at gene promoters is associated with the decrease in gene expression. ${ }^{66}$ In B-cell NHLs, DNA methylation is dysregulated, and consequently results in the aberrant expression of genes involved in lymphomagenesis. ${ }^{67}$ DNA hypermethylation results in the repression of miR-124a expression, which in turn results in the overexpression of oncogenic $C D K 6 .{ }^{68}$ Similarly, in several hematological malignancies, DNA hypermethylation results in the repression of miR-203, which enhances the expression of oncogenic $A B L 1$ and BCR-ABL1 fusion genes. ${ }^{69}$ In some instances, DNA hypermethylation could provide an alternative means for Myc activation. In the absence of the Myc-IGH translocation (in BL-translocation-negative cases) miR-9 is hypermethylated, resulting in its downregulation and upregulation of its oncogenic target, Myc. ${ }^{32}$ 
Histone modifications, unlike DNA methylation, involve the covalent modification of histone residues, rather than of DNA nucleotides. miRNAs may influence histone marks by regulating the expression of histone modifiers. In MCL, miR-15a, miR-16-1, and miR-29 are downregulated due to histone hyperacetylation at the promoters of their genes. In this instance, the hyperacetylation is brought about by the overexpression of Myc: Myc binds to and represses HDAC3, an enzyme that is responsible for removing acetyl groups from histone residues. This in turn results in the downregulation of miR-15a/16-1. ${ }^{38}$ In a subsequent study by the same group, Myc was observed to work in concert with $E Z H 2$ to repress $H D A C 3$, which in turn resulted in the repression of $\operatorname{miR}-29 .{ }^{37}$

\section{Viral infection}

In some cases, miRNA dysregulation can be induced by viral infections. Some variants of NHLs involve the presence of $\mathrm{EBV}$, an oncogenic herpes virus that establishes a latent infection in lymphocytes. ${ }^{2}$ EBV readily transforms B-cells into permanently growing cells under certain conditions such as immunosuppression. EBV is implicated in $95 \%$ of endemic BL cases and $15 \%$ of DLBCL cases. EBV-transformed cells include at least 44 mature viral miRNAs that target viral and endogenous genes. ${ }^{71}$ For example, three viral miRNAs (ebv-mir-BHRF1-3) are upregulated in EBV-positive tumors, and are responsible for the downregulation of CXCL11. This targeted suppression of CXCL11 by a viral-encoded miRNA may serve as an immunomodulatory mechanism for tumorigenesis. ${ }^{72}$ EBV-specific miRNAs, ebv-mir-BART3, ebv-mir-BART9, and ebv-mir-BART17-5p, are upregulated in tumors and target $B C L 6$, a transcription factor that typically represses many genes involved in lymphomagenesis. BCL6 is also disrupted in NHLs by translocations, but their repression by viral miRNA suggests other mechanisms by which BCL6 could be repressed. ${ }^{73}$ In addition to introducing viral miRNAs into cells, EBV induces and represses the expression of several endogenous cellular miRNAs. When comparing EBV-positive with EBV-negative DLBCL cases, a distinct miRNA expression profile for EBV-positive DLBCL cases revealed nine upregulated miRNAs and seven downregulated miRNAs. ${ }^{74}$ Similarly, in splenic marginal zone lymphoma (SMZL), a less common B-cell lymphoma, tumor-suppressive miR-26 was found to be downregulated in chronic hepatitis $\mathrm{C}$ virus (HCV)-positive tumors compared with HCV-negative tumors. ${ }^{75}$ These results suggest that the oncogenic potential of viruses could be, in part, mediated by miRNAs.

\section{miRNA-specific mechanisms of dysregulation}

The above mechanisms of dysregulation can also affect protein-coding genes; the following, however, is a miRNAspecific dysregulation mechanism. Dysregulation of miRNA expression can also occur posttranscriptionally during miRNA biogenesis. ${ }^{76}$ Both Drosha and Dicer are enzymes that play key roles in processing pri- and pre-miRNA, respectively, in the miRNA biogenesis pathway. They are not only required for the biogenesis of endogenous miRNAs in B-cells, but are also essential for the biogenesis of miRNAs introduced by EBV. ${ }^{77}$ In particular, the expression level of Dicer is crucial for the maintenance of cellular homeostasis. The loss of one functional allele of Dicer in BL cells ${ }^{70}$ and DLBCL tumors ${ }^{49}$ results in impaired miRNA biogenesis and, consequently, an accumulation of the pri-miRNA, which cannot be processed into mature miRNA. However, the complete loss of Dicer prevents lymphomagenesis and is selected against in tumors: one functional allele of Dicer is required for the tumor survival, whereas deletion of both alleles of Dicer in B-cells does not promote tumorigenesis, but instead induces apoptosis. ${ }^{78}$

Specific RNA-binding proteins are also required for the biogenesis of some miRNA. This is illustrated by the biogenesis of miR-18a from the miR-17-92 cluster. Although all six miRNAs from this cluster are transcribed together as a polycistron, miR-18a additionally requires the presence of hnRNP A1 for its maturation. ${ }^{79}$ Although the targets of each of the members of this miRNA cluster do overlap because of the high degree of conservation between the miRNA members, this finding suggests that therapeutically targeting miR-18a alone could fine-tune the expression levels of miR-17-92 targets.

More recently, an atypical miRNA biogenesis pathway has been found in germinal center B-cells, where miRNA can be derived from transfer RNA (tRNA) molecules that undergo Dicer cleavage. Of interest is the tRNA-derived miRNA CU1276 that is strongly downregulated in GCB-lymphomas compared with normal germinal center B-cells, and targets RPA1, a modulator of DNA damage response in the germinal center. ${ }^{80}$ This finding describes a novel pretranslational regulatory potential for tRNA fragments that are abundantly expressed in cells, and suggests that tRNAs may be relevant to miRNA-based therapies.

\section{Synergy of mechanisms of dysregulation}

An individual miRNA may be dysregulated by multiple mechanisms, but the co-occurrence (and implied synergy) 
of these mechanisms of dysregulation could exacerbate the aberrant expression of the miRNAs. miRNAs from the miR-17-92 cluster are the most frequently overexpressed in B-cell NHLs. ${ }^{19}$ This is likely due to the variety of mechanisms that can result in their dysregulation: copy number amplifications, translocations, aberrant transcriptional regulation by Myc, and the presence of specific RNA-binding proteins. ${ }^{79}$ Similarly, the characteristic downregulation of miR-155 in BL tumors is achieved by two mechanisms, one at the transcriptional level and one at the post-processing level. At the transcriptional level, repression is mediated by transcription factors Protein kinase $\mathrm{C}$ and nuclear factor kappa-light-chainenhancer of activated B cells, while at the post-processing level, there is an accumulation of the pri-miRNA of miR$155(B I C)$ due to the inability of BL cells BIC to process mature miRNA. ${ }^{70}$ These findings underscore the significance of the dysregulation of these miRNA in lymphomagenesis, but, more importantly, they indicate that therapies can be designed to address their aberrant expression at either the transcriptional or biogenesis levels.

In addition to dysregulation of miRNA expression, miRNA-mediated repression can be disrupted as a consequence of dysregulation and mutation of mRNA targets. For instance, MCL tumors preferentially express an mRNA transcript variant that arises as a consequence of point mutations and genomic deletions. This truncated splice variant lacks the miR-16 binding site, thus escapes MMR, and results in an upregulation of truncated CCND1. ${ }^{81}$ Sandberg et al ${ }^{82}$ and Mayr et $\mathrm{al}^{83}$ have also demonstrated more generally that proliferating cells tend to produce mRNA transcripts with shorter 3'-UTRs, suggesting that many more such mRNA splice-variant specific miRNA:mRNA interactions still have yet to be discovered.

\section{The therapeutic potential of miRNA miRNA as a diagnostic tool in NHL}

Current NHL classification and diagnostic techniques rely on a combination of morphologic, biologic, and clinical features to distinguish between NHL subtypes, and thus are unable to accurately classify NHL tumors into specific subtypes. ${ }^{2}$ Moreover, recent evidence has challenged the idea of a precise separation between NHL subtypes and suggests that each NHL case should be treated based on its genetic and molecular characteristics. For instance, molecular aberrations may be insufficient to differentiate NHL subtypes - DLBCL and high-grade FL share the $\mathrm{t}(14 ; 18)$ translocation - but grade $3 \mathrm{~b}$ FL has a higher relapse rate and may require a different treatment regimen. ${ }^{84}$
Likewise, although $\mathrm{t}(8 ; 14)$ translocations characterize most cases of $\mathrm{BL}$, there are some translocation-negative $\mathrm{BL}$ cases that still display Myc-mediated gene and miRNA dysregulation. ${ }^{32,59}$

miRNAs are a promising new class of biomarkers that may supplement NHL diagnosis. Their suitability as biomarkers stems from their widespread dysregulation and characteristic expression profiles. One group has demonstrated the feasibility of the expression of the six miRNAs from the miR-17-92 cluster in accurately distinguishing between GCB-DLBCL and FL cases. ${ }^{85}$ Several studies ${ }^{33,35,86}$ have determined that miR-155 expression can distinguish BL from DLBCL cases.

Unlike mRNA, miRNAs are stable in vitro and long-lived in vivo, and can be detected in urine, peripheral blood, and formalin-fixed paraffin-embedded (FFPE) tissues. ${ }^{87}$ Tissue samples collected during surgery, as well as biopsies, are often fixed in FFP, but extracting nucleic acids from FFPE tissue has been problematic. However, since there are several methods that can reliably profile miRNAs in FFPE tissue, including quantitative polymerase chain reaction, in situ hybridization, ${ }^{75}$ and microarrays,${ }^{88}$ miRNA research in archival tissue is rapidly gaining popularity.

Circulating miRNAs have several characteristics that make them suitable noninvasive diagnostic biomarkers: blood serum miRNA are resistant to RNase digestion and other harsh conditions such as extreme $\mathrm{pH}$, boiling, extended storage, and multiple freeze-thaw cycles. ${ }^{89}$ When considering the circulating miRNA profiles of serum from DLBCL patients compared with healthy subjects, one study found elevated expression of miR-155, miR-210, and miR-21, ${ }^{90}$ and a subsequent study additionally found elevated expression of miR-15a, miR-16-1, and miR-29c and decreased expression of miR-34a. ${ }^{91}$ As such, the utility of circulating miRNAs as noninvasive biomarkers in NHL diagnosis is promising.

\section{miRNA as a prognostic tool in NHL}

miRNAs may also serve as noninvasive biomarkers at the prognostic level, where they can be used to predict patient outcome and to monitor patients after chemotherapy. Several studies have identified miRNAs that have expression profiles associated with patient outcomes (Table 3). Of note is a study that has found that high miR-21 levels in the serum of DLBCL patients indicates relapse-free survival. ${ }^{90}$ Similarly, another group found that the downregulation of miR-92a in blood plasma of complete-response NHL patients indicates an increased probability of disease relapse. ${ }^{92}$ 


\section{Correcting for aberrantly expressed miRNA}

Given the large impact of miRNA on tumorigenesis, miRNA-based cancer therapeutics are being designed to correct the aberrant expression of miRNA. Miravirsen (Santaris Pharma A/S, Hørsholm, Denmark), the first miRNAbased therapeutic tested in humans, is currently undergoing Phase II clinical trials for the treatment of HCV infections. ${ }^{93}$ miRNA therapy is advantageous because it is extremely specific in its targeting: a partial complementary basepairing interaction is required between the miRNA $\sim 7 \mathrm{nt}$ seed sequence and mRNA. Moreover, a single miRNA can act as a "master switch," and thus can concurrently target numerous mRNA targets and may be useful where several oncogenic pathways need to be targeted simultaneously. ${ }^{94}$ As such, the majority of currently developed miRNA-based therapeutics take the form of miRNA mimics or miRNA inhibitors that can normalize the expression of their target genes (reviewed in Iorio and Croce ${ }^{95}$ ). In the context of NHLs, one study has successfully demonstrated Locked nucleic acid-mediated anti-miR-155 silencing in B-cell lymphomas in mice. ${ }^{96}$ However, the development of miRNA therapeutics in NHLs is still in its infancy, probably due to the confounding results of miRNA therapeutic experiments. For instance, in testing the tumor-suppressor activity of miR-34a, one study reported that, not only did miR-34a not inhibit cell proliferation, it resulted in proapoptotic activity by dysregulation of the c-MYC/p53 regulatory axis. ${ }^{97}$ This suggests that the attribute of miRNA as a master switch could result in many off-target effects, which we currently lack a complete understanding of.

Despite this, therapeutically targeting the causes of miRNA dysregulation in NHL directly can still be considered. For instance, aberrantly expressed transcription factors or epigenetic modifiers that regulate miRNA expression can be directly targeted to reverse dysregulation of miRNA and other targets of the epigenetic modifiers. One specific example would be the therapeutic targeting of collaborative oncogenic partners $H D A C$ and $E Z H 2$ to restore the expression of tumor-suppressive miR-29 and other HDAC and EZH2 targets in MCL cell lines. In a recent study, this restoration was achieved by the combined inhibition of HDAC and EZH2 (through vorinostat, DZNep, or their small interfering RNA). As a consequence, a reduction of oncogenic CDK6 and insulin-like growth factor (IGF)-1R and subsequent inhibition of cell survival and colony formation in vitro was observed. ${ }^{37}$ In another study, downregulation of miR-17, miR-18, miR-15b, miR-34a, and miR-155 was achieved by dose-dependent vorinostat and trichostatin A treatments in cell lines, and promoted a set of proapoptotic changes. ${ }^{98}$

\section{Personalized medicine}

Since miRNA dysregulation is heterogeneous within and between NHL types, treating each NHL patient based on the particular molecular aberrations their disease presents might result in better outcomes. In the age of personalized medicine, it is likely that miRNA genotypes and miRNA and mRNA expression and epigenetic profiles for each patient will be readily available for the identification of molecular aberrations that define a particular patients disease. With this information, clinicians and scientists could move from prescribing a uniform treatment regime to all NHL patients to instead designing patient-specific therapies that may precisely supplement or antagonize the identified dysregulated miRNA in that patient's disease. In addition, if dysregulation of miRNA biogenesis machinery is identified, perhaps therapies could be designed to correct dysregulated expression of Dicer and Drosha. If proper miRNA biogenesis can be restored, it would avoid having the replacement of individual miRNA species, which could result in a myriad of off-target effects.

Drug resistance is a major obstacle to the successful treatment of DLBCL - nearly half of the patients treated with the cyclophosphamide, doxorubicin, vincristine, prednisone (CHOP) regimen stop responding to treatment and become drug resistant. At the level of prognosis, certain miRNA have been found to regulate the sensitivity of patients to particular drug regiments. miR-21 expression levels in DLBCL cell lines is relatively high, and miR-21 knockdown can significantly downregulate the expression level of PTEN protein and thereby increase the sensitivity of DLBCL cell lines to the CHOP chemotherapeutic regimen. ${ }^{99}$ Similarly, miR-148b levels were upregulated in response to radiation treatment of DLBCL cell lines, and were found to inhibit proliferation and increase radiosensitivity by enhancing radiation-induced apoptosis. Identifying miRNA expression levels of these miRNA that regulate treatment sensitivity would aid in the development of individualized treatment plans for DLBCL patients with abnormal expression of these miRNA, in order to increase the efficacy of treatment regimens. ${ }^{100}$

\section{Conclusion}

Recent work has increased our understanding of dysregulation of miRNA expression across diverse types of B-cell NHL. This coordinated dysregulation of miRNA expression 
systematically results in the activation of several oncogenic pathways, and consequently the reprogramming of the B-cell NHL transcriptomes. miRNA dysregulation is a consequence of several mechanisms, ranging from dysregulation of the DNA sequences encoding the miRNA, to transcriptional regulation of miRNA loci, to dysregulation of the miRNA biogenesis pathway or dysregulation of mRNA targets. The widespread dysregulation of miRNA suggests that, not only can it be used not only as a diagnostic and prognostic tool, but its mechanisms of dysregulation can be used as actionable drug targets. An understanding of the mechanisms of miRNA dysregulation as summarized here can perhaps better inform the design of miRNA-based therapeutic strategies and lead to better survival for NHL patients.

\section{Disclosure}

The authors report no conflicts of interest in this work.

\section{References}

1. Staudt LM. Aggressive lymphomas. N Engl J Med. 2010;362(15): $1417-1429$.

2. Campo E, Swerdlow SH, Harris NL, Pileri S, Stein H, Jaffe ES. The 2008 WHO classification of lymphoid neoplasms and beyond: evolving concepts and practical applications. Blood. 2011;117(19): 5019-5032.

3. Alizadeh AA, Eisen MB, Davis RE, et al. Distinct types of diffuse large B-cell lymphoma identified by gene expression profiling. Nature. 2000;403(6769):503-511.

4. Sinha R, Nastoupil L, Flowers CR. Treatment strategies for patients with diffuse large B-cell lymphoma: past, present, and future. Blood Lymphat Cancer. 2012;2012:87-98.

5. Chalfie M, Horvitz HR, Sulston JE. Mutations that lead to reiterations in the cell lineages of C. elegans. Cell. 1981;24(1):59-69.

6. Kozomara A, Griffiths-Jones S. miRBase: integrating microRNA annotation and deep-sequencing data. Nucleic Acids Res. 2011;39(Database issue):D152-D157.

7. Han J, LeeY, Yeom KH, et al. Molecular basis for the recognition of primary microRNAs by the Drosha-DGCR8 complex. Cell. 2006;125(5): 887-901.

8. Krol J, Loedige I, Filipowicz W. The widespread regulation of microRNA biogenesis, function and decay. Nat Rev Genet. 2010;11(9): 597-610.

9. Schnall-Levin M, Rissland OS, Johnston WK, Bartel DP, Berger B. Unusually effective microRNA targeting within repeat-rich coding regions of mammalian mRNAs. Genome Res. 2011;21(9): 1395-1403.

10. Vasudevan S, Tong Y, Steitz JA. Switching from repression to activation: microRNAs can up-regulate translation. Science. 2007; 318(5858):1931-1934.

11. Creighton CJ, Reid JG, Gunaratne PH. Expression profiling of microRNAs by deep sequencing. Brief Bioinform. 2009;10(5): 490-497.

12. Hsu SD, Lin FM, Wu WY, et al. miRTarBase: a database curates experimentally validated microRNA-target interactions. Nucleic Acids Res. 2011;39(Database issue):D163-D169.

13. Croce CM. Causes and consequences of microRNA dysregulation in cancer. Nat Rev Genet. 2009;10(10):704-714.

14. Calin GA, Croce CM. MicroRNA signatures in human cancers. Nat Rev Cancer. 2006;6(11):857-866.

15. Lu J, Getz G, Miska EA, et al. MicroRNA expression profiles classify human cancers. Nature. 2005;435(7043):834-838.
16. Fernando TR, Rodriguez-Malave NI, Rao DS. MicroRNAs in B cell development and malignancy. J Hematol Oncol. 2012;5:7.

17. Sandhu SK, Croce CM, Garzon R. Micro-RNA expression and function in lymphomas. Adv Hematol. 2011;2011:347137.

18. Calin GA, Dumitru CD, Shimizu M, et al. Frequent deletions and down-regulation of micro- RNA genes miR15 and miR16 at 13q14 in chronic lymphocytic leukemia. Proc Natl Acad Sci U SA. 2002;99(24): 15524-15529.

19. Lawrie CH. MicroRNA expression in lymphoma. Expert Opin Biol Ther. 2007;7(9):1363-1374.

20. Zhang J, Jima DD, Jacobs C, et al. Patterns of microRNA expression characterize stages of human B-cell differentiation. Blood. 2009; 113(19):4586-4594.

21. Malumbres R, Sarosiek KA, Cubedo E, et al. Differentiation stagespecific expression of microRNAs in B lymphocytes and diffuse large B-cell lymphomas. Blood. 2009;113(16):3754-3764.

22. Basso K, Sumazin P, Morozov P, et al. Identification of the human mature B cell miRNome. Immunity. 2009;30(5):744-752.

23. Auer RL. The coming of age of microRNA for B cell lymphomas. Histopathology. 2011;58(1):39-48.

24. Di Lisio L, Martinez N, Montes-Moreno S, Piris-Villaespesa M, Sanchez-Beato M, Piris MA. The role of miRNAs in the pathogenesis and diagnosis of B-cell lymphomas. Blood. 2012;120(9):1782-1790.

25. Roehle A, Hoefig KP, Repsilber D, et al. MicroRNA signatures characterize diffuse large B-cell lymphomas and follicular lymphomas. Br J Haematol. 2008;142(5):732-744.

26. Robertus JL, Harms G, Blokzij1 T, et al. Specific expression of miR-17-5p and miR-127 in testicular and central nervous system diffuse large B-cell lymphoma. Mod Pathol. 2009;22(4):547-555.

27. Lenz G, Wright GW, Emre NC, et al. Molecular subtypes of diffuse large B-cell lymphoma arise by distinct genetic pathways. Proc Natl Acad Sci U S A. 2008;105(36):13520-13525.

28. Culpin RE, Proctor SJ, Angus B, Crosier S, Anderson JJ, Mainou-Fowler T. A 9 series microRNA signature differentiates between germinal centre and activated B-cell-like diffuse large B-cell lymphoma cell lines. Int J Oncol. 2010;37(2):367-376.

29. Lawrie $\mathrm{CH}$, Soneji S, Marafioti T, et al. MicroRNA expression distinguishes between germinal center B cell-like and activated B cell-like subtypes of diffuse large B cell lymphoma. Int J Cancer. 2007;121(5):1156-1161.

30. Wang W, Corrigan-Cummins M, Hudson J, et al. MicroRNA profiling of follicular lymphoma identifies microRNAs related to cell proliferation and tumor response. Haematologica. 2012;97(4):586-594.

31. Lawrie CH, Chi J, Taylor S, et al. Expression of microRNAs in diffuse large B cell lymphoma is associated with immunophenotype, survival and transformation from follicular lymphoma. J Cell Mol Med. 2009;13(7):1248-1260.

32. Onnis A, De Falco G, Antonicelli G, et al. Alteration of microRNAs regulated by c-Myc in Burkitt lymphoma. PLoS ONE. 2010;5(9). pii:e12960.

33. Lenze D, Leoncini L, Hummel M, et al. The different epidemiologic subtypes of Burkitt lymphoma share a homogenous micro RNA profile distinct from diffuse large B-cell lymphoma. Leukemia. 2011; 25(12):1869-1876.

34. Dave SS, Fu K, Wright GW, et al. Molecular diagnosis of Burkitt's lymphoma. $N$ Engl J Med. 2006;354(23):2431-2442.

35. Kluiver J, Haralambieva E, de Jong D, et al. Lack of BIC and microRNA miR-155 expression in primary cases of Burkitt lymphoma. Genes Chromosomes Cancer. 2006;45(2):147-153.

36. Rosenwald A, Wright G, Wiestner A, et al. The proliferation gene expression signature is a quantitative integrator of oncogenic events that predicts survival in mantle cell lymphoma. Cancer Cell. 2003; 3(2):185-197.

37. Zhang X, Zhao X, Fiskus W, et al. Coordinated silencing of MYCmediated miR-29 by HDAC3 and EZH2 as a therapeutic target of histone modification in aggressive B-Cell lymphomas. Cancer Cell. 2012;22(4):506-523. 
38. Zhang $X$, Chen $X$, Lin J, et al. Myc represses miR-15a/miR-16-1 expression through recruitment of HDAC3 in mantle cell and other nonHodgkin B-cell lymphomas. Oncogene. 2012;31(24):3002-3008.

39. Navarro A, Bea S, Fernández V, et al. MicroRNA expression, chromosomal alterations, and immunoglobulin variable heavy chain hypermutations in Mantle cell lymphomas. Cancer Res. 2009;69(17): 7071-7078.

40. Craig VJ, Cogliatti SB, Imig J, et al. Myc-mediated repression of microRNA-34a promotes high-grade transformation of B-cell lymphoma by dysregulation of FoxP1. Blood. 2011;117(23): 6227-6236.

41. Li C, Kim SW, Rai D, et al. Copy number abnormalities, MYC activity, and the genetic fingerprint of normal B cells mechanistically define the microRNA profile of diffuse large B-cell lymphoma. Blood. 2009; 113(26):6681-6690.

42. Klein U, Lia M, Crespo M, et al. The DLEU2/miR-15a/16-1 cluster controls B cell proliferation and its deletion leads to chronic lymphocytic leukemia. Cancer Cell. 2010;17(1):28-40.

43. Deshpande A, Pastore A, Deshpande AJ, et al. 3’UTR mediated regulation of the cyclin D1 proto-oncogene. Cell Cycle. 2009;8(21): 3584-3592.

44. Zhao JJ, Lin J, Lwin T, et al. microRNA expression profile and identification of miR-29 as a prognostic marker and pathogenetic factor by targeting CDK6 in mantle cell lymphoma. Blood. 2010;115(13): 2630-2639.

45. Bueno MJ, Gómez de Cedrón M, Gómez-López G, et al. Combinatorial effects of microRNAs to suppress the Myc oncogenic pathway. Blood. 2011;117(23):6255-6266.

46. Xiao C, Srinivasan L, Calado DP, et al. Lymphoproliferative disease and autoimmunity in mice with increased miR-17-92 expression in lymphocytes. Nat Immunol. 2008;9(4):405-414.

47. Rao E, Jiang C, Ji M, et al. The miRNA-17-92 cluster mediates chemoresistance and enhances tumor growth in mantle cell lymphoma via PI3K/ AKT pathway activation. Leukemia. 2012;26(5):1064-1072.

48. Ventura A, Young AG, Winslow MM, et al. Targeted deletion reveals essential and overlapping functions of the miR-17 through 92 family of miRNA clusters. Cell. 2008;132(5):875-886

49. Eis PS. Accumulation of miR-155 and BIC RNA in human B cell lymphomas. Proc Natl Acad Sci U S A. 2005;102(10): 3627-3632.

50. Dorsett Y, McBride KM, Jankovic M, et al. MicroRNA-155 suppresses activation-induced cytidine deaminase-mediated Myc-Igh translocation. Immunity. 2008;28(5):630-638.

51. Huang X, Shen Y, Liu M, et al. Quantitative proteomics reveals that miR-155 regulates the PI3K-AKT pathway in diffuse large B-cell lymphoma. Am J Pathol. 2012;181(1):26-33.

52. Rai D, Kim SW, McKeller MR, Dahia PL, Aguiar RC. Targeting of SMAD5 links microRNA-155 to the TGF-beta pathway and lymphomagenesis. Proc Natl Acad Sci U S A. 2010;107(7):3111-3116.

53. Sandhu SK, Volinia S, Costinean S, et al. miR-155 targets histone deacetylase 4 (HDAC4) and impairs transcriptional activity of B-cell lymphoma 6 (BCL6) in the E $\mu$-miR-155 transgenic mouse model. Proc Natl Acad Sci U S A. 2012;109(49):20047-20052.

54. Chen W, Houldsworth J, Olshen AB, et al. Array comparative genomic hybridization reveals genomic copy number changes associated with outcome in diffuse large B-cell lymphomas. Blood. 2006; 107(6):2477-2485.

55. Calin GA, Sevignani C, Dumitru CD, et al. Human microRNA genes are frequently located at fragile sites and genomic regions involved in cancers. Proc Natl Acad Sci U S A. 2004;101(9):2999-3004.

56. Schneider B, Nagel S, Kaufmann M, et al. T(3;7)(q27;q32) fuses BCL6 to a non-coding region at FRA7H near miR-29. Leukemia. 2008;22(6):1262-1266.

57. Ruiz-Ballesteros E, Mollejo M, Mateo M, Algara P, Martínez P, Piris MA. MicroRNA losses in the frequently deleted region of $7 q$ in SMZL. Leukemia. 2007;21(12):2547-2549.
58. Schneider B, Nagel S, Ehrentraut S, et al. Neoplastic MiR-17-92 deregulation at a DNA fragility motif (SIDD). Genes Chromosomes Cancer. 2012;51(3):219-228.

59. Leich E, Zamo A, Horn H, et al. MicroRNA profiles of t(14;18)-negative follicular lymphoma support a late germinal center B-cell phenotype. Blood. 2011;118(20):5550-5558.

60. Huppi K, Volfovsky N, Runfola T, et al. The identification of microRNAs in a genomically unstable region of human chromosome 8q24. Mol Cancer Res. 2008;6(2):212-221.

61. Meyer N, Penn LZ. Reflecting on 25 years with MYC. Nat Rev Cancer. 2008;8(12):976-990.

62. Chang TC, Yu D, Lee YS, et al. Widespread microRNA repression by Myc contributes to tumorigenesis. Nat Genet. 2008;40(1):43-50.

63. Robertus JL, Kluiver J, Weggemans C, et al. MiRNA profiling in B non-Hodgkin lymphoma: a MYC-related miRNA profile characterizes Burkitt lymphoma. Br J Haematol. 2010;149(6):896-899.

64. O’Donnell KA, Wentzel EA, Zeller KI, Dang CV, Mendell JT. c-Myc-regulated microRNAs modulate E2F1 expression. Nature. 2005;435(7043):839-843

65. Ducasse M, Brown MA. Epigenetic aberrations and cancer. Mol Cancer. 2006;5(1):60.

66. Herman JG, Baylin SB. Gene silencing in cancer in association with promoter hypermethylation. N Engl J Med. 2003;349(21):2042-2054.

67. Shaknovich R, Geng H, Johnson NA, et al. DNA methylation signatures define molecular subtypes of diffuse large B-cell lymphoma. Blood. 2010;116(20):e81-e89.

68. Wong KY, So CC, Loong F, et al. Epigenetic inactivation of the miR-124-1 in haematological malignancies. PLoS ONE. 2011;6(4): e19027.

69. Chim CS, Wong KY, Leung CY, et al. Epigenetic inactivation of the hsa-miR-203 in haematological malignancies. J Cell Mol Med. 2011;15(12):2760-2767.

70. Kluiver J, van den Berg A, de Jong D, et al. Regulation of pri-microRNA $\mathrm{BIC}$ transcription and processing in Burkitt lymphoma. Oncogene. 2007;26(26):3769-3776.

71. Barth S, Meister G, Grässer FA. EBV-encoded miRNAs. Biochim Biophys Acta. 2011;1809(11-12):631-640.

72. Xia T, O'Hara A, Araujo I, et al. EBV microRNAs in primary lymphomas and targeting of CXCL-11 by ebv-mir-BHRF1-3. Cancer Res. 2008;68(5):1436-1442.

73. Martín-Pérez D, Vargiu P, Montes-Moreno S, et al. Epstein-Barr virus microRNAs repress BCL6 expression in diffuse large B-cell lymphoma. Leukemia. 2012;26(1):180-183.

74. Imig J, Motsch N, Zhu JY, et al. microRNA profiling in Epstein-Barr virus-associated B-cell lymphoma. Nucleic Acids Res. 2011;39(5): 1880-1893.

75. Peveling-Oberhag J, Crisman G, Schmidt A, et al. Dysregulation of global microRNA expression in splenic marginal zone lymphoma and influence of chronic hepatitis C virus infection. Leukemia. 2012;26(7): $1654-1662$.

76. Thomson JM, Newman M, Parker JS, Morin-Kensicki EM, Wright T, Hammond SM. Extensive post-transcriptional regulation of microRNAs and its implications for cancer. Genes Dev. 2006;20(16): 2202-2207.

77. Kim do N, Lee SK. Biogenesis of Epstein-Barr virus microRNAs. Mol Cell Biochem. 2012;365(1-2):203-210.

78. Arrate MP, Vincent T, Odvody J, Kar R, Jones SN, Eischen CM. MicroRNA biogenesis is required for Myc-induced B-cell lymphoma development and survival. Cancer Res. 2010;70(14):6083-6092.

79. Ji M, Rao E, Ramachandrareddy H, et al. The miR-17-92 microRNA cluster is regulated by multiple mechanisms in B-cell malignancies. Am J Pathol. 2011;179(4):1645-1656.

80. Maute RL, Schneider C, Sumazin P, et al. tRNA-derived microRNA modulates proliferation and the DNA damage response and is downregulated in B cell lymphoma. Proc Natl Acad Sci U S A. 2013;110(4): 1404-1409. 
81. Chen RW, Bemis LT, Amato CM, et al. Truncation in CCND1 mRNA alters miR-16-1 regulation in mantle cell lymphoma. Blood. 2008;112(3):822-829.

82. Sandberg R, Neilson JR, Sarma A, Sharp PA, Burge CB. Proliferating cells express mRNAs with shortened $3^{\prime}$ untranslated regions and fewer microRNA target sites. Science. 2008;320(5883):1643-1647.

83. Mayr C, Hemann MT, Bartel DP. Disrupting the pairing between let-7 and Hmga2 enhances oncogenic transformation. Science. 2007;315(5818):1576-1579.

84. Tada K, Kim S-W, Asakura Y, et al. Comparison of outcomes after allogeneic hematopoietic stem cell transplantation in patients with follicular lymphoma, diffuse large B-cell lymphoma associated with follicular lymphoma, or de novo diffuse large B-cell lymphoma. $\mathrm{Am}$ J Hematol. 2012;87(8):770-775.

85. Fassina A, Marino F, Siri M, et al. The miR-17-92 microRNA cluster: a novel diagnostic tool in large B-cell malignancies. Lab Invest. 2012;92(11):1574-1582.

86. Kluiver J, Poppema S, de Jong D, et al. BIC and miR-155 are highly expressed in Hodgkin, primary mediastinal and diffuse large B cell lymphomas. J Pathol. 2005;207(2):243-249.

87. Pritchard CC, Cheng HH, Tewari M. MicroRNA profiling: approaches and considerations. Nat Rev Genet. 2012;13(5):358-369.

88. Nelson PT, Baldwin DA, Scearce LM, Oberholtzer JC, Tobias JW, Mourelatos Z. Microarray-based, high-throughput gene expression profiling of microRNAs. Nat Methods. 2004;1(2):155-161.

89. Ma R, Jiang T, Kang X. Circulating microRNAs in cancer: origin, function and application. J Exp Clin Cancer Res. 2012; $31: 38$.

90. Lawrie CH, Gal S, Dunlop HM, et al. Detection of elevated levels of tumour-associated microRNAs in serum of patients with diffuse large B-cell lymphoma. Br J Haematol. 2008;141(5):672-675.

91. Fang C, Zhu DX, Dong HJ, et al. Serum microRNAs are promising novel biomarkers for diffuse large B cell lymphoma. Ann Hematol. 2012;91(4):553-559.

92. Ohyashiki K, Umezu T, Yoshizawa S, et al. Clinical impact of downregulated plasma miR-92a levels in non-Hodgkin's lymphoma. PLoS One. 2011;6(2):e16408.

93. Lindow M, Kauppinen S. Discovering the first microRNA-targeted drug. J Cell Biol. 2012;199(3):407-412.

94. Garzon R, Marcucci G, Croce CM. Targeting microRNAs in cancer: rationale, strategies and challenges. Nat Rev Drug Discov. 2010;9(10):775-789.

95. Iorio MV, Croce CM. MicroRNA dysregulation in cancer: diagnostics, monitoring and therapeutics. A comprehensive review. EMBO Mol Med. 2012;4(3):143-159.

96. Zhang Y, Roccaro AM, Rombaoa C, et al. LNA-mediated anti-miR-155 silencing in low-grade B-cell lymphomas. Blood. 2012;120(8): $1678-1686$

97. Rizzo M, Marian L, Cavallini S, Simili M, Rainaldi G. The overexpression of miR-34a fails to block DoHH2 lymphoma cell proliferation by reducing 533 via c-MYC down-regulation. Nucleic Acid Ther. 2012;22(4) 283-288.

98. Kretzner L, Scuto A, Dino PM, et al. Combining histone deacetylase inhibitor vorinostat with aurora kinase inhibitors enhances lymphoma cell killing with repression of c-Myc, hTERT, and microRNA levels. Cancer Res. 2011;71(11):3912-3920.

99. Bai H, Wei J, Deng C, Yang X, Wang C, Xu R. MicroRNA-21 regulates the sensitivity of diffuse large B-cell lymphoma cells to the CHOP chemotherapy regimen. Int J Hematol. 2013;97(2): 223-231.

100. Wu Y, Liu GL, Liu SH, et al. MicroRNA-148b enhances the radiosensitivity of non-Hodgkin's Lymphoma cells by promoting radiationinduced apoptosis. J Radiat Res. 2012;53(4):516-525.

101. Di Lisio L, Gómez-López G, Sánchez-Beato M, et al. Mantle cell lymphoma: transcriptional regulation by microRNAs. Leukemia. 2010;24(7):1335-1342.
102. Nie K, Zhang T, Allawi H, et al. Epigenetic down-regulation of the tumor suppressor gene PRDM1/Blimp-1 in diffuse large B cell lymphomas: a potential role of the microRNA let-7. Am J Pathol. 2010;177(3):1470-1479.

103. Lin J, Lwin T, Zhao JJ, et al. Follicular dendritic cell-induced microRNA-mediated upregulation of PRDM1 and downregulation of BCL-6 in non-Hodgkin's B-cell lymphomas. Leukemia. 2011;25(1):145-152.

104. Kim SW, Ramasamy K, Bouamar H, Lin AP, Jiang D, Aguiar RC. MicroRNAs miR-125a and miR-125b constitutively activate the NF- $\mathrm{\kappa B}$ pathway by targeting the tumor necrosis factor alpha-induced protein 3 (TNFAIP3, A20). Proc Natl Acad Sci U SA. 2012;109(20):7865-7870.

105. Akao Y, Nakagawa Y, Kitade Y, Kinoshita T, Naoe T. Downregulation of microRNAs-143 and -145 in B-cell malignancies. Cancer Sci. 2007;98(12):1914-1920.

106. Xiao C, Calado DP, Galler G, et al. MiR-150 controls B cell differentiation by targeting the transcription factor c-Myb. Cell. 2007;131(1): $146-159$.

107. Teng G, Hakimpour P, Landgraf P, et al. MicroRNA-155 is a negative regulator of activation-induced cytidine deaminase. Immunity. 2008;28(5):621-629.

108. Thompson RC, Herscovitch M, Zhao I, Ford TJ, Gilmore TD. NFkappaB down-regulates expression of the B-lymphoma marker CD10 through a miR-155/PU.1 pathway. J Biol Chem. 2011;286(3): $1675-1682$.

109. Pedersen IM, Otero D, Kao E, et al. Onco-miR-155 targets SHIP1 to promote TNFalpha-dependent growth of $\mathrm{B}$ cell lymphomas. EMBO Mol Med. 2009;1(5):288-295.

110. Cimmino A, Calin GA, Fabbri M, et al. miR-15 and miR-16 induce apoptosis by targeting BCL2. Proc Natl Acad Sci U SA. 2005;102(39): 13944-13949.

111. Jiang P, Rao EY, Meng N, Zhao Y, Wang JJ. MicroRNA-17-92 significantly enhances radioresistance in human mantle cell lymphoma cells. Radiat Oncol. 2010;5:100.

112. Alencar AJ, Malumbres R, Kozloski GA, et al. MicroRNAs are independent predictors of outcome in diffuse large B-cell lymphoma patients treated with R-CHOP. Clin Cancer Res. 2011;17(12):4125-4135.

113. Lwin T, Lin J, Choi YS, et al. Follicular dendritic cell-dependent drug resistance of non-Hodgkin lymphoma involves cell adhesion-mediated Bim down-regulation through induction of microRNA-181a. Blood. 2010;116(24):5228-5236.

114. Bueno MJ, Pérez de Castro I, Gómez de Cedrón M, et al. Genetic and epigenetic silencing of microRNA-203 enhances ABL1 and BCRABL1 oncogene expression. Cancer Cell. 2008;13(6):496-506.

115. Craig VJ, Cogliatti SB, Rehrauer H, Wündisch T, Müller A. Epigenetic silencing of microRNA-203 dysregulates ABL1 expression and drives Helicobacter-associated gastric lymphomagenesis. Cancer Res. 2011;71(10):3616-3624.

116. Leucci E, Cocco M, Onnis A, et al. MYC translocation-negative classical Burkitt lymphoma cases: an alternative pathogenetic mechanism involving miRNA deregulation. J Pathol. 2008;216(4):440-450.

117. Pal S, Baiocchi RA, Byrd JC, Grever MR, Jacob ST, Sif S. Low levels of miR-92b/96 induce PRMT5 translation and H3R8/ H4R3 methylation in mantle cell lymphoma. EMBO J. 2007;26(15): 3558-3569.

118. Sampson VB, Rong NH, Han J, et al. MicroRNA let-7a down-regulates MYC and reverts MYC-induced growth in Burkitt lymphoma cells. Cancer Res. 2007;67(20):9762-9770.

119. Volinia S, Galasso M, Costinean S, et al. Reprogramming of miRNA networks in cancer and leukemia. Genome Res. 2010;20(5): 589-599.

120. Schiffman JD, Lorimer PD, Rodic V, et al. Genome wide copy number analysis of paediatric Burkitt lymphoma using formalin-fixed tissues reveals a subset with gain of chromosome 13q and corresponding miRNA over expression. Br J Haematol. 2011;155(4):477-486. 
121. Guil S, Cáceres JF. The multifunctional RNA-binding protein hnRNP A1 is required for processing of miR-18a. Nat Struct Mol Biol. 2007;14(7):591-596.

122. Chigrinova $\mathrm{E}, \mathrm{Mian} \mathrm{M}$, Shen $\mathrm{Y}$, et al. Integrated profiling of diffuse large B-cell lymphoma with 7q gain. Br J Haematol. 2011;153(4):499-503.

123. Montes-Moreno S, Martinez N, Sanchez-Espiridión B, et al. miRNA expression in diffuse large B-cell lymphoma treated with chemoimmunotherapy. Blood. 2011;118(4):1034-1040
124. Zhong H, Xu L, Zhong JH, et al. Clinical and prognostic significance of miR-155 and miR-146a expression levels in formalin-fixed/paraffinembedded tissue of patients with diffuse large B-cell lymphoma. Exp Ther Med. 2012;3(5):763-770.

125. Berglund M, Hedström G, Amini RM, Enblad G, Thunberg U. High expression of microRNA-200c predicts poor clinical outcome in diffuse large B-cell lymphoma. Oncol Rep. 2013;29(2):720-724.

\section{Publish your work in this journal}

Blood and Lymphatic Cancer: Targets and Therapy is an international, peer-reviewed, open access journal focusing on blood and lymphatic cancer research, identification of therapeutic targets and the optimal use of preventative and integrated treatment interventions to achieve improved outcomes, enhanced survival and quality of life for the cancer patient. The manuscript management system is completely online and includes a very quick and fair peer-review system. Visit http://www.dovepress.com/testimonials.php to read real quotes from published authors. 